\title{
ANALISIS MANFAAT INVESTASI TEKNOLOGI INFORMASI MENGGUNAKAN METODE IT VALUATION DI KANTOR SINODE GMIM
}

\author{
Christhy Mononimbar ${ }^{1)}$, Yaulie Rindengan ${ }^{2)}$, Nancy Tuturoong ${ }^{3)}$, Stanley Karouw ${ }^{4)}$ \\ ${ }^{1,2,3,4}$ Program Studi Teknik Informatika, Fakultas Teknik, Universitas Sam Ratulangi \\ Jl. Kampus UNSRAT Bahu, Manado, 95115 \\ Telp : (0431) 852959, Fax : (0431) 823705 \\ E-mail: christhymononimbar@gmail.com ${ }^{1)}$, stanley.karouw @ unsrat.ac.id ${ }^{4)}$
}

\begin{abstract}
Abstrak
Gereja, sebagai organisasi perlu mengoptimalkan manfaat Teknologi Informasi (TI) untuk kepentingan manajemen organisasi. TI merupakan salah satu factor pemungkin (key enabler )yang mendukung efisiensi manajemen organisasi gereja. Mengetahui hasil manfaat dari suatu investasi TI adalah langkah awal untuk mengukur manfaat TI dalam gereja, sebagai organisasi non-profit. Metode IT Valuation Matrix dapat digunakan untuk mengidentifikasi, mengklasifikas dan mengkuantifikasi setiap manfaat TI dari investasi yang sudah dilakukan. Hasil kuantifikasi manfaat bisnis diukur dari setiap project TI yang telah dilakukan dan menunjukan besaran manfaat terukur yang sigifikan untuk organisasi non-profit seperti gereja
\end{abstract}

Kata Kunci: Investasi TI, Manfaat Bisnis TI, IT Valuation Matrix, Organisasi Non Profit

\section{Pendahuluan}

Perkembangan dan penggunaan produk Teknologi Informasi (TI) telah menjadi suatu hal yang primer dikalangan masyarakat, karena di tahun-tahun belakangan ini, TI telah menjadi salah satu faktor yang diperlukan dalam menunjang berbagai pekerjaan. Bukan hanya pada organisasi profit saja, pada orgaisasi non-profit juga penggunaan produk TI pun telah menjadi hal yang wajar dan sering dilakukan. Perusahaan atau organisasi yang tidak menggunakan produk TI dalam melaksanakan tugasnya, akan mengalami kesulitan dalam banyak hal, mengingat banyak pekerjaan yang dulunya dilakukan dengan cara manual, telah digantikan dengan sistem komputerisasi yang terbukti memberikan kemudahan, efektifitas, dan efesiensi dari segi biaya dan tenaga kerja. Investasi TI yang diterapkan oleh organisasi non-profit, jika dilihat dari besarnya nilai investasi, seringkali ditemukan nilai investasi yang cukup besar, mengingat suatu organisasi non-profit benar-benar merasa perlu menggunakan produk TI tersebut. Jika ditanya tentang manfaat intangible, banyak yang tidak memiliki data-data yang sesuai. Padahal, pengurangan atau pengeliminasian kontribusi manfaat intangible ini telah mengurangi nilai Return on Investment investasi TI tersebut. Dalam Tata Kelola TI, evaluasi investasi TI dan pengukuran manfaat bisnis menjadi salah satu faktor yang penting. Beberapa ahli merumuskan beberapa metode penghitungan investasi TI, yang juga memperhitungkan manfaat berbasis value. Penggabungan kuantifikasi manfaat dengan value yang optimal diharapkan akan memberikan hasil yang lebih baik dan akurat. Salah satunya adalah metode IT Valuation Matriks, dimana metode ini dapat menghitung nilai atau manfaat terhitung dan tidak terhitung pada suatu organisasi.

Masalah yang ingin dijawab dalam penelitian ini adalah bagaimana menghitung nilai manfaat investasi TI pada organisasi non-profit seperti di Kantor Sinode Gereja Masehi Injili di Minahasa (GMIM)?.

\section{Manfaat Bisnis TI}

Manfaat bisnis TI (IT business value $)^{[1][2][3]}$ didefinisikan sebagai manfaat atau hasil yang diperoleh dari suatu investasi TI yang dapat meningkatkan kinerja organisasi. Pengertian manfaat bisnis ini, lebih dari sekedar memberikan benefit atau keuntungan secara finansial saja. Manfaat bisnis didasarkan atas pemikiran bagaimana TI bisa memberikan menjamin efisiensi, efektivitas, meningkatkan produktivitas hingga menciptakan keunggulan kompetitif tertentu bagi organisasi. Pengertian manfaat ini mengikuti pemahaman Parker $^{[4][5]}$, dimana menurut Bannister dan Remenyi ${ }^{[6]}$ didasarkan atas definisi Porter ${ }^{[7]}$ tentang value.

Upaya untuk mengidentifikasi dan mengklasifikasi manfaat bisnis TI telah dilakukan oleh beberapa orang. Parker ${ }^{[4][5]}$ membedakan 
manfaat bisnis TI menjadi: 1) Manfaat tangible yakni manfaat TI yang mudah diukur; 2). Manfaat intangible; yakni manfaat TI yang sulit untuk diukur; 3). Diantara kedua manfaat tersebut terdapat manfaat quasi-intangible. Remenyi et.al ${ }^{[8]}$ membedakan klasifikasi manfaat bisnis TI menjadi: 1). Easy to quantify (EQT) atau hard benefit; 2). Hard-to-quantify Tangible (HQT); 3). Easy-to-quantify Intangible (EQI); 4). Hard-toquantify Intangible (HQI) atau strategic/soft benefit. Perlu dicermati bahwa, usaha mengidentifikasi dan mengklasifikasikan manfaat bisnis TI tersebut diatas dilakukan berdasarkan pendekatan positivist-methodology. Menurut Bannister dan Remenyi ${ }^{[6]}$, selain menggunakan pendekatan diatas, identifikasi dan klasifikasi manfaat bisnis TI, dapat juga dilakukan berdasarkan pendekatan hermeneutic. Proses identifikasi dan klasifikasi dengan menggunakan pendekatan hermeneutic ini dilakukan oleh Ranti $^{[1][2]}$

Menurut hasil penelitian yang dilakukan Ranti ${ }^{[1]}$, dengan mengambil studi kasus di Indonesia, maka terdapat 13 kategori dan 73 subkategori manfaat bisnis TI. Jika dibandingkan dengan beberapa negara berkembang lainnya, maka terdapat 3 manfaat bisnis TI yang unik untuk Indonesia. Ketiga manfaat bisnis TI itu adalah: 1). (Reducing cost of) subscription cost selected reading materials or subscription cost per employee, dapat diartikan sebagai pengurangan biaya berlangganan untuk materi bacaan tertentu (misalnya koran atau majalah elektronik) atau biaya langganan setiap karyawan. 2) (Increasing image caused by) complying with regulations, yang dapat diartikan sebagai memperkuat image suatu organisasi karena turut mematuhi aturan-aturan tertentu, yang mengikat organisasi tersebut. 3)(Increasing image caused by) using branded system, yang dapat diartikan sebagai meningkatkan image organisasi karena menggunakan suatu aplikasi tertentu yang terkenal. Manfaat bisnis TI generik hasil penelitian Ranti ${ }^{[1]}$ selengkapnya dapat dilihat pada Gambar 1 dibawah ini:

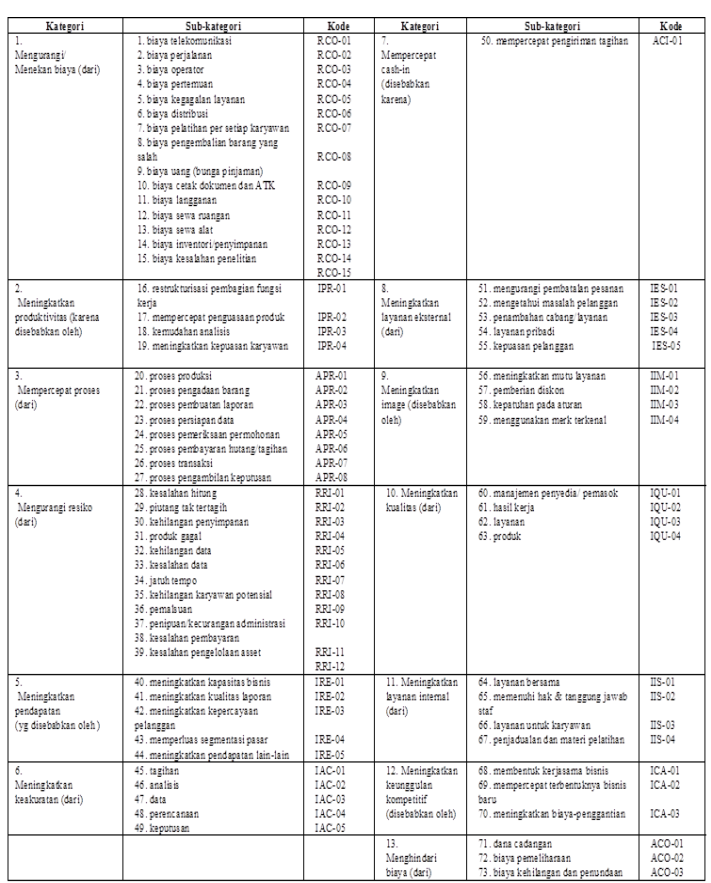

Gambar. 1. Manfaat Bisnis TI menrut Ranti ${ }^{[1]}$

Karouw $^{[11]}$ telah melakukan identifikasi dan klasifikasi manfaat bisnis TI spesifik organisasi nir laba, yakni Pemda. Karouw ${ }^{[11]}$ mengikuti pendekatan hermeneutics Ranti ${ }^{[1]}$ dan menggunakan Tabel Ranti's Generic IS/IT Business Value $^{[1]}$ dalam proses identifikasi dan klasifikasi manfaat bisnit TI spesifik untuk Pemda. Hasil identifikasi dan klasifikasi manfaat bisnis TI untuk Pemda terdapat 9 kategori dan 18 sub-kategori manfaat bisnis TI spesifik Pemda, yakni: mempercepat proses (APR), mengurangi resiko (IRR), mengurangi biaya (RCO), meningkatkan produktivitas (IPR), meningkatkan pendapatan (IRE), meningkatkan layanan eksternal (IES), meningkatkan kualitas (IQU) dan meningkatkan kualitas dari layanan internal (IIS). Manfaat bisnis APR merupakan manfaat bisnis yang paling sering disebut sedangkan manfaat bisnis IRR merupakan manfaat bisnis yang paling banyak memiliki sub-kategori manfaat bisnis. Selain itu, manfaat bisnis TI generic yang unik di Indonesia, juga teridentifikasi pada Pemda, yakni Increasing image (IIM) caused by menggunakan merk terkenal dan kepatuhan pada aturan. Selengkapnya dapat dilihat pada Gambar 2 berikut.

Evaluasi investasi TI, menurut Ranti ${ }^{[2][3]}$ dilakukan berdasarkan beberapa alasan, yakni:

1) Untuk mendapatkan justifikasi dari suatu proyek TI. 


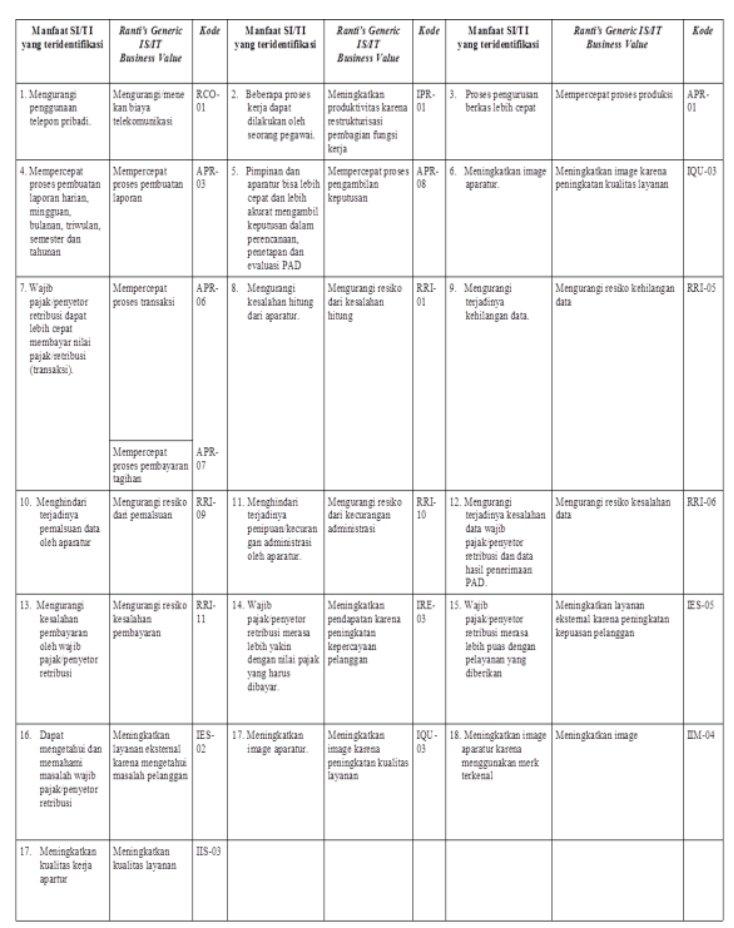

Gambar. 2. Manfaat Bisnis TI Spesifik Pemda

2) Memampukan organisasi untuk menilai investasi dari berbagai proyek TI yang dilakukan dengan berbagai keterbatasan sumber daya organisasi.

3) Menyediakan berbagai alat ukur untuk memonitor dan mengendalikan investasi TI yang telah dan akan dilakukan.

4) Memampukan organisasi untuk menciptakan keunggulan kompetitif, mengembangkan bisnis baru, memperbaiki kinerja dan produktivitas, dan memberikan cara baru dalam mengelola organisasi.

Ranti $^{[2][3]}$ memaparkan beberapa metodologi konvensional guna mengevaluasi manfaat bisnis TI yakni Information Economics (IE) dari Parker $^{[4][5]}$ Real Option Valuation (ROV), Balanced Scorecard (BSC), Economic Value Added (EVA), Return On Management (ROM), dan Multi-Objective Multi Criteria (MOMC). Metodologi konvensional ini juga disebutkan oleh Indrajit $^{[10]}$. Pada dasarnya metode pengukuran konvensional tersebut diatas memiliki keunggulan dan kelemahannya masing-masing. Remenyi ${ }^{[7]}$ menyarankan untuk menggunakan 2 atau 3 matriks pengukuran, dan menghindari penggunaan matriks pengukuran yang terlalu banyak.

$\mathrm{IE}^{[4][5]}$ mengukur manfaat $\mathrm{TI}$ dengan menggunakan pendekatan finansial dalam bentuk SimpleROI, sedangkan untuk pendekatan non finansial dengan mengelompokkan manfaat bisnis sebagai Value Linking (VL), Value Acceleration (VA), Value Restructuring (VR), Value
Innovation (VI), Strategic Match (SM), Competitive Advantage (CA), Management Information (MI), Competitive Response (CR), Project or Organizational Risk (OR).

$\operatorname{Read}^{[11]}$ mengembangkan suatu metode yang disebut IT Value Network. Pendekatan Read ${ }^{[1]}$ juga memperhitungkan pendekatan finansial dan pendekatan non-finansial. Tahapan evaluasi investasi TI dari Read ${ }^{[11]}$ mengikuti langkahlangkah: 1) Identifying, 2) Justifying, 3) Prioritizing, 4) Selecting, 5) Performing, dan 6) Realizing. Setiap langkah ini memiliki pasangan 12 alat ukur finansial (seperti ROI/DCF/NPV/IRR, Budgeting, Business Case, Investment Review Board, Audit, EAV, TCO, Decision Trees, Real Options dan IT Risk Management) dan 12 alat ukur non-finansial (seperti Strategic Planning, Operational Planning, Program and Project Management, IT Governance, Critical Success Factor, IT balanced scorecard, Benchmarking, Surveys, Service Level Agreements, IT portofolio management dan Scenario Planning). Untuk membantu identifikasi manfaat bisnis TI, maka Read ${ }^{[10]}$ menggolongkan setiap produk TI dengan Model Category $4 S$ : Shared - infrastructure, Systems - operations, Services - stakeholder, Strategic - informational.

Ranti $^{[12]}$ mengembangkan suatu metode evaluasi investasi TI berdasarkan manfaat bisnis TI. Metode ini disebut IT Valuation Matrix. Pendekatan Ranti ${ }^{[12]}$ juga memperhitungkan pendekatan finansial dan non finansial. (Lihat $\mathrm{Gbr}$ 3).

Ranti $^{[12]}$ membedakan terlebih dahulu jenis investasi menurut kategori mandatory, improvement, strategic dan infrastructure. Dimana masing-masing kategori investasi TI tersebut memiliki focus, assessment, value dan proses quantification yang berbeda

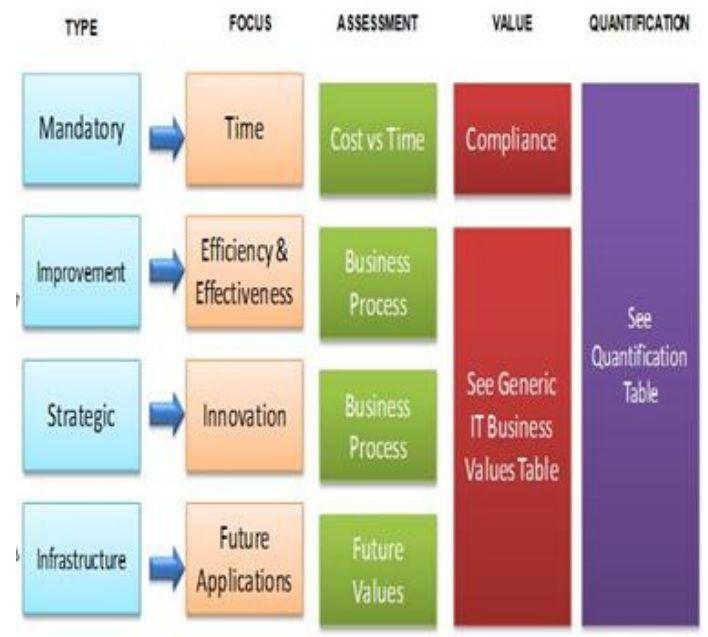

Gambar. 3 Kerangka Kerja IT Valuation Matrix 


\section{Metodologi Pemecahan Masalah}

Penelitian yang dilakukan bersifat studi kasus. Obyek studi kasus adalah Kantor Sinode Gereja Masehi Injili di Minahasa (GMIM).

Untuk keperluan pengumpulan data, akan dilakukan dengan cara: menyebarkan kuesioner; melakukan wawancara; melakukan diskusi kelompok; melakukan studi pustaka. Data yang ditemukan dikaji secara kualitatif berdasarkan metode hermeneutics. Langkah-langkah pemecahan masalah akan mengikuti kerangka kerja IT Valuation Matrix seperti pada Gambar 3 diatas.

Secara detail, langkah-langkah pemecahan masalah adalah:

1) Analisis Ientifikasi/Menggali Manfaat Bisnis TI

2) Mengkuantifikasi Manfaat Bisnis TI dengan aktivitas: klasifikasi, kuantifikasi dan klarifikasi

3) Mengkuantifikasi Manfaat Bisnis TI dengan Pendekatan berbasis Value

4) Mengembangkan Tools Aplikasi Perhitungan Manfaat Bisnis TI

\section{Pembahasan}

\subsection{Analisis Identifikasi Manfaat}

Proses untuk menghasilkan manfaat bisnis dari suatu organisasi adalah Identifikasi Manfaat Bisnis TI. Kegiatan ini merupakan proses ke 2 dari metode penelitian. Setelah memperoleh hasil identifikasi manfaat pada organisasi ini, hasil tersebut dibuat dalam bentuk digram manfaat bisnis TI. Diagram manfaat bisnis ini merupakan proses ke 3 dari metode penelitian. Masukkan yang diperlukan adalah buku teks, jurnal dan hasil kuisioner.

Dari masukkan yang ada maka terdapat manfaat bisnis penggunaan aplikasi Pendataan Ekonomi Jemaat yang ada di Kantor Sinode GMIM sebagai berikut :

1. Mengurangi biaya telepon pribadi

2. Mengurangi biaya perjalan pegawai Kantor Sinode GMIM

3. Mengurangi biaya pelatihan

4. Meminimalisir biaya cetak dokumen

5. Mengurangi resiko terjadinya kesalahan hitung

6. Kurangnya resiko kehilangan data

7. Mengurangi resiko kesalahan input data

8. Menghindari terjadinya kecurangan administrasi

9. Mempermudah pegawai menganalisis pekerjaan

10. Meningkatkan kepuasan pegawai dalam kerjanya
11. Meningkatkan image pegawai karena tahu menggunakan aplikasi baru

Analisis manfaat bisnis yang teridentifikasi diatas, jika dipetakan pada Tabel Ranti's IS/IT Generic Business Value diatas dapat diuraikan sebagai berikut :

\section{Reducing Cost (RCO)}

Menekan biaya merupakan salah satu manfaat yang didapat dari pengimplementasian aplikasi pendataan ekonomi jemaat di Kantor Sinode GMIM, maka RCO yang tepat adalah :

a. Mengurangi biaya telekomunikasi ( RCO01) sesuai hasil pengamatan, wawancara dan kuisioner yang diperoleh menunjukan bahwa pemakaian handphone dan pemakaian telepon kantor, merupakan sarana komunikasi pelaporan yang digunakan oleh setiap pegawai. Implementasi aplikasi Pendataan Ekonomi Jemaat serta adanya jaringan internet dapat menekan biaya telekomunikasi antara Kantor Sinode GMIM dan Jemaat-Jemaat yang ada di Minahasa.

b. Mengurangi biaya perjalanan (RCO-02) hasil wawancara dan kuisioner menunjukan implementasi aplikasi pendataan ekonomi jemaat dapat menekan biaya perjalanan pegawai misalnya kurangnya biaya bensin yang dikeluarkan karena pegawai tidak harus terjun langsung ke jemaat yang ada.

c. Mengurangi biaya pelatihan per setiap pegawai ( RCO-07) implementasi aplikasi ini dapat menekan biaya pelatihan yang sering dikeluarkan oleh pihak kantor misalnya pelatihan yang sering dilaksanakan secara triwulan dioptimalkan menjadi 6 bulan sekali, sehingga mengurangi biaya konsumsi, biaya narasumber, biaya cetak materi dan biaya lainnya yang terkait dengan itu.

d. Biaya cetak dokumen (RCO-10), implementasi aplikasi ini dapat mengurangi biaya cetak dokumen karena laporan yang dulunya berbentuk hardcopy, sekarang bisa dilihat dalam bentuk softcopy melalui computer, sehingga memperkecil biaya pencetakan dokumen dalam bentuk hardcopy.

2. Reducing Risk (RRI)

Proses pengolahan data yang dilakukan oleh Kantor Sinode GMIM dapat dikatakan sulit karena melibatkan seluruh jemaat yang ada di Minahasa, sehingga harus dilakukannya perhitungan yang akurat. Perhitungan inilah yang sangat berkaitan dengan data jemaat. Manfaat yang diperoleh dengan adanya implementasi TI di sini adalah sebagai berikut :

a. Mengurangi resiko kesalahan hitung (RRI-01), dengan adanya system komputer yang 
terintegrasi akan mengurangi terjadinya kesalahan hitung dana jemaat misalnya dalam hal ini persembahan tiap jemaat yang ada di GMIM. Aplikasi ini juga dapat mengurangi resiko kesalahan hitung dalam proses rekapitulasi data jemaat.

b. Mengurangi resiko kehilangan data ( RRI-05), informasi disimpan dalam bentuk database, dimana informasi tersebut dapat di backup dibanyak perangkat computer sehingga meminimalisir resiko terjadinya kehilangan data.

c. Mengurangi resiko terjadinya kesalahan input data ( RRI-06), akan muncul pemberitahuan jika user salah menginput data sehingga data tersebut dapat segera direvisi, sehingga resiko kesalahan input data tersebut dapat diminimalisir.

d. Mengurangi resiko dari kecurangan administrasi ( RRI-10), database yang telah disimpan dapat langsung diperiksa oleh atasan, sehingga menghindari terjadinya kecurangan administrasi.

3. Increasing Productivity (IPR)

Peningkatan produktivitas berkaitan dengan meningkatkan sumber daya manusia yang ada. Manfaat yang diperoleh dari implementasi TI adalah :

a. Mempermudah pegawai menganalisis pekerjaan (IPR-04), dengan adanya fitur search dapat mempermudah pencarian data sesuai kebutuhan user, sehingga proses analisis dapat dikerjakan dengan mudah dan lebih efisien.

b. Meningkatkan kepuasan pegawai (IPR-05), system yang dibangun memiliki interface yang baik dan memiliki fitur-fitur yang optimal sesuai kebutuhan user.

4. Increasing Image (IIM)

a. Meningkatkan image pegawai karena tahu menggunakan aplikasi baru (IIM-04) mendorong user untuk belajar sehingga bisa terbiasa menggunakan aplikasi tersebut dengan demikian dapat meningkatkan kualitas kerja user dan merekaa bangga tahu menggunakan aplikasi tersebut.

Jika dipetakan pada Tabel Ranti's IS/IT Generic Business Value, maka identifikasi manfaat bisnis tersebut diatas dapat dilihat pada Tabel 1 dibawah ini.

Tabel 1. Pemetaan Manfaat Bisnis Teridentifikasi pada Ranti's Generic IS/IT Business Value

\begin{tabular}{|l|l|l|}
\hline $\begin{array}{l}\text { Manfaat SI/TI yang } \\
\text { teridentifikasi }\end{array}$ & $\begin{array}{l}\text { Ranti Generic IS/IT } \\
\text { Business Value }\end{array}$ & Kode \\
\hline $\begin{array}{l}\text { 1.Mengurangi biaya } \\
\text { telepon pribadi }\end{array}$ & Biaya Telekomunikasi & RCO-01 \\
\hline
\end{tabular}

\begin{tabular}{|c|c|c|}
\hline \begin{tabular}{ll}
$\begin{array}{l}\text { Mengurangi } \\
\text { perjalan }\end{array}$ & biaya \\
pegawai Kantor \\
\multicolumn{2}{l}{ Sinode GMIM }
\end{tabular} & Biaya Perjalanan & $\mathrm{RCO}-02$ \\
\hline $\begin{array}{l}\text { Mengurangi biaya } \\
\text { pelatihan }\end{array}$ & $\begin{array}{l}\text { Biaya pelatihan per } \\
\text { setiap pegawai }\end{array}$ & RCO-07 \\
\hline $\begin{array}{l}\text { Meminimalisir biaya } \\
\text { cetak dokumen }\end{array}$ & Biaya cetak dokumen & RCO-10 \\
\hline $\begin{array}{l}\text { Mengurangi resiko } \\
\text { terjadinya kesalahan } \\
\text { hitung }\end{array}$ & Kesalahan hitung & RRI-01 \\
\hline $\begin{array}{l}\text { Kurangnya resiko } \\
\text { kehilangan data }\end{array}$ & Kehilngan data & RRI-05 \\
\hline $\begin{array}{l}\text { Mengurangi resiko } \\
\text { kesalahan input data }\end{array}$ & Kesalahan input data & RRI-06 \\
\hline $\begin{array}{l}\text { Menghindari } \\
\text { terjadinya } \\
\text { kecurangan } \\
\text { administrasi }\end{array}$ & $\begin{array}{l}\text { Penipuan/kecurangan } \\
\text { administrasi }\end{array}$ & RRI-10 \\
\hline $\begin{array}{l}\text { Mempermudah } \\
\text { pegawai } \\
\text { menganalisis } \\
\text { pekerjaan }\end{array}$ & Kemudahan analisis & IPR-04 \\
\hline $\begin{array}{l}\text { Meningkatkan } \\
\text { kepuasan pegawai } \\
\text { dalam kerjanya }\end{array}$ & $\begin{array}{l}\text { Meningkatkan } \\
\text { kepuasan pegawai }\end{array}$ & IPR-05 \\
\hline $\begin{array}{l}\text { Meningkatkan image } \\
\text { pegawai karena tahu } \\
\text { menggunakan } \\
\text { aplikasi baru }\end{array}$ & $\begin{array}{l}\text { Menggunakan merk } \\
\text { terkenal }\end{array}$ & IIM-04 \\
\hline
\end{tabular}

\subsection{Analisis Kuantifikasi Manfaat Bisnis TI}

Kuantifikasi manfaat bisnis TI merupakan proses ke-2 dari metode penelitian. Memperoleh manfaat dari implementasi aplikasi terhadap kantor Sinode GMIM merupakan tujuan yang diharapkan mereka. Proses kuantifikasi berpedoman pada metode Ranti's IT Valuation Matrix. Berdasarkan hasil wawancara, dan studi literatur maka strategi TI kantor Sinode GMIM bertipe improvement dan infrastructure. Investasi bertipe Improvement yaitu untuk peningkatan efisiensi dan efektivitas proses bisnis yang dalam hal ini dimiliki oleh kantor Sinode GMIM lebih khusus bagian data dan informasi. Sedangkan investasi tipe Infrastructure lebih berfokus pada manfaat yang akan diperoleh pada masa mendatang dengan mengembangkan aplikasi yang sudah ada guna mencapai tujuan bisnis Kantor Sinode GMIM.

Hasil analisis manfaat bisnis yang telah dijelaskan sebelumnya menunjukan bahwa manfaat bisnis kategori menekan biaya (RCO) dan mengurangi rasiko (RRI) yang sering ditemui sesuai dengan wawancara kepada narasumber dan hasil responden. Berdasarkan manfaat bisnis yang diperoleh, maka akan dibuat perhitungan sesuai dengan 5 kategori yang telah didapat. Pengidentifikasian dan penamaan manfaat bisnis dalam pendekatan financial menggunakan Tabel Manfaat Bisnis TI Generik dan pendekatan NonFinancial ada 3 (tiga) ranah yang akan dikaji dengan system scoring dan pembobotan yang 
dikembangkan oleh Benny Ranti dan menghasilkan perhitungan sebagai berikut :

4.3.1 Tangible Values

Total biaya pembangunan yang dikeluarkan oleh kantor Sinode GMIM untuk investasi Sistem Informasi Pendataan Ekonomi Jemaat sebesar Rp 47.215.500, untuk lebih lengkapnya dapat dilihat padaGambar 5 berikut.

Setelah menggunakan aplikasi Pendataan Ekonomi Jemaat, terjadi penekanan biaya didalam beberapa bagian sehingga memberikan keuntungan atau penghematan bagi Kantor Sinode GMIM. Penekanan biaya yang dimaksud dapat dilihat pada tabel 2 dibawah ini :

\begin{tabular}{|c|c|c|}
\hline \multicolumn{2}{|c|}{ 1. Nama Proyek } & $\begin{array}{l}\text { Sistem Informasi Pendataan } \\
\text { Ekonomi Jemaat }\end{array}$ \\
\hline \multicolumn{2}{|r|}{ - Nilai Investasi } & Rp. 47.215 .500 \\
\hline \multicolumn{2}{|r|}{ - Tipe Investasi } & $\begin{array}{l}\text { Improvement dan } \\
\text { Infrastructure }\end{array}$ \\
\hline \multicolumn{3}{|c|}{ Identifikasi Biaya } \\
\hline \multicolumn{2}{|r|}{ - Biaya Implementasi } & Rp. 25.000 .000 \\
\hline \multicolumn{2}{|c|}{ • Biaya Operasi } & Rp0 \\
\hline \multicolumn{3}{|c|}{ Identifikasi Manfaat } \\
\hline \multicolumn{2}{|r|}{ - Penekanan Biaya } & Rp 156.200.000 \\
\hline \multicolumn{2}{|r|}{ - Mengurangi Resiko } & Rp 1.747.200.000 \\
\hline \multicolumn{2}{|r|}{ - Meningkatkan Produktivitas } & Rp 58.800.000 \\
\hline \multicolumn{2}{|r|}{ - MeningkatkanPendapatan } & Rp 57.600.000 \\
\hline \multicolumn{2}{|r|}{ - Meningkatkan Image } & Rp 4.200.000 \\
\hline
\end{tabular}

Gambar 5. Biaya Pembangunan Aplikasi Pendataan Jemaat

Tabel 2. Penekanan Biaya

\begin{tabular}{|c|c|c|c|}
\hline No & $\begin{array}{c}\text { Mengurangi/ } \\
\text { menekan } \\
\text { biaya dari }\end{array}$ & Perhitungan & Total \\
\hline 1 & $\begin{array}{l}\text { Biaya } \\
\text { Telekomunikasi }\end{array}$ & $\begin{array}{l}\text { Rp } 300.000 \times \\
14 \text { x } 12 \\
a=\text { pemakaian } \\
\text { per bulan } \\
b=\text { jumlah staf } \\
\text { yang } \\
\text { menggunakan } \\
\text { telekomunikasi } \\
c=12 \text { bulan }\end{array}$ & Rp. 50.400 .000 \\
\hline 2 & $\begin{array}{l}\text { Biaya } \\
\text { Perjalanan }\end{array}$ & $\begin{array}{l}\text { Rp. } 25.000 \times 22 \\
\times 14 \times 12 \\
a=\text { biaya } \\
\text { perjalanan per } \\
\text { hari } \\
b=22 \text { hari kerja } \\
c=\text { jumlah staf } \\
d=12 \text { bulan }\end{array}$ & $\begin{array}{l}\mathrm{Rp} \\
92.400 .000 .000\end{array}$ \\
\hline 3 & Biaya pelatihan & $\begin{array}{l}100 \times \text { Rp. } \\
50.000 \\
a=\text { jumlah } \\
\text { orang yang ikut } \\
\text { pelatihan } \\
\mathrm{b}=\text { biaya } \\
\text { pendaftaran }\end{array}$ & Rp 5.000.000 \\
\hline 4 & $\begin{array}{l}\text { Biaya cetak } \\
\text { dokumen }\end{array}$ & $\begin{array}{l}\text { Rp. } 50.000 \times 14 \\
\text { x } 12 \\
a=\text { biaya cetak } \\
\text { dokumen } \\
b=\text { jumlah } \\
\text { pegawai } \\
c=12 \text { bula }\end{array}$ & $\operatorname{Rp} 8.400 .000$ \\
\hline & & Total & $\begin{array}{l}\text { Rp } \\
156.200 .000\end{array}$ \\
\hline
\end{tabular}

Sesuai hasil pengamatan, wawancara dan kuisioner yang diperoleh menunjukan bahwa pemakaian handphone dan pemakaian telepon kantor, merupakan sarana komunikasi pelaporan yang digunakan oleh setiap pegawai. Implementasi aplikasi Pendataan Ekonomi Jemaat serta adanya jaringan internet dapat menekan biaya telekomunikasi antara Kantor Sinode GMIM dan Jemaat-Jemaat yang ada di Minahasa. Implementasi aplikasi pendataan ekonomi jemaat juga dapat menekan biaya perjalanan pegawai misalnya kurangnya biaya bensin yang dikeluarkan karena pegawai tidak harus terjun langsung ke jemaat yang ada. Implementasi aplikasi ini dapat menekan biaya pelatihan yang sering dikeluarkan oleh pihak kantor misalnya pelatihan yang sering dilaksanakan secara triwulan dioptimalkan menjadi 6 bulan sekali, sehingga mengurangi biaya konsumsi, biaya narasumber, biaya cetak materi dan biaya lainnya yang terkait dengan itu. Biaya cetak dokumen (RCO-10), implementasi aplikasi ini dapat mengurangi biaya cetak dokumen karena laporan yang dulunya berbentuk hardcopy, sekarang bisa dilihat dalam bentuk softcopy melalui computer, sehingga memperkecil biaya pencetakan dokumen dalam bentuk hardcopy. Rangkuman biaya-biaya tersebut diatas dapat dilihat pada Tabel 3.

Tabel 3 Rangkuman Penekanan Biaya

\begin{tabular}{|c|c|c|}
\hline Kategori & Sub-Kategori & Nilai \\
\hline \multirow{4}{*}{$\begin{array}{l}\text { Mengurangi / } \\
\text { Menekan } \\
\text { biaya dari }\end{array}$} & $\begin{array}{l}\text { Biaya } \\
\text { telekomunikasi }\end{array}$ & Rp. 50.400 .000 \\
\hline & $\begin{array}{l}\text { Biaya } \\
\text { perjalanan }\end{array}$ & Rp 92.400.000.000 \\
\hline & Biaya pelatihan & Rp 5.000.000 \\
\hline & $\begin{array}{l}\text { Biaya cetak } \\
\text { dokumen }\end{array}$ & $\operatorname{Rp} 8.400 .000$ \\
\hline & Total & Rp 156.200.000 \\
\hline
\end{tabular}

Selanjutnya pada penggunaan aplikasi ini terdapat beberapa kemungkinan resiko yang dapat terjadi sehingga memberikan pengaruh pada penghematan biaya Kantor Sinode. Nilai tersebut dapat dilihat pada Tabel 4.

Tabel 4. Perhitungan Pengurangan Resiko

\begin{tabular}{|c|c|c|c|}
\hline No & $\begin{array}{l}\text { Mengurangi } \\
\text { Resiko dari }\end{array}$ & Perhitungan & Total \\
\hline 1 & $\begin{array}{l}\text { Kesalahan } \\
\text { hitung }\end{array}$ & $\begin{array}{l}\text { Rp. } 750.000 \times \\
40 \% \text { x } 14 \times 12 \\
a=\text { jumlah uang } \\
\text { setiap bulan } \\
\text { b= prediksi } \\
\text { akibat } \\
\text { kesalahan } \\
\text { hitung } \\
c=\text { jumlah staf } \\
\text { yang salah } \\
\text { hitung } \\
d=12 \text { bulan }\end{array}$ & $\begin{array}{l}\text { Rp. } \\
504.000 .000\end{array}$ \\
\hline
\end{tabular}




\begin{tabular}{|c|c|c|c|}
\hline 2 & Kehilangan data & $\begin{array}{l}\text { Rp. } 300.000 \times 3 \\
\text { x } 14 \text { x } 12 \\
a=\text { prediksi } \\
\text { besarnya biaya } \\
\text { kehilangan data } \\
b=\text { banyaknya } \\
\text { data yang hilang } \\
c=\text { jumlah staf } \\
d=12 \text { bulan }\end{array}$ & $\begin{array}{l}\text { Rp. } \\
\text { 151.200.000 }\end{array}$ \\
\hline 3 & $\begin{array}{l}\text { Kesalahan input } \\
\text { data }\end{array}$ & $\begin{array}{l}\text { Rp. } 500.000 \times 3 \\
\text { x } 14 \text { x } 12 \\
a=\text { prediksi } \\
\text { besarnya biaya } \\
\text { kesalahan input } \\
\text { data } \\
b=\text { banyaknya } \\
\text { data yang } \\
\text { diinput } \\
c=\text { jumlah staf } \\
d=12 \text { bulan }\end{array}$ & $\begin{array}{l}\text { Rp. } \\
252.000 .000\end{array}$ \\
\hline 4 & $\begin{array}{l}\text { Kecurangan } \\
\text { administrasi }\end{array}$ & $\begin{array}{l}\text { Rp. } 1.000 .000 \times \\
5 \times 14 \times 12 \\
a=\text { biaya } \\
\text { kecurangan } \\
\text { administrasi } \\
\text { b = banyaknya } \\
\text { yang melakukan } \\
\text { kecurangan } \\
c=\text { jumlah staf } \\
\text { korban } \\
\text { kecurangan } \\
d=12 \text { bulan }\end{array}$ & Rp.840.000.000 \\
\hline \multicolumn{3}{|c|}{ Total } & $\begin{array}{l}\text { Rp } \\
1.747 .200 .000\end{array}$ \\
\hline
\end{tabular}

\begin{tabular}{|c|c|c|c|}
\hline & & $\begin{array}{l}\text { pegawai } \\
b=\text { jumlah } \\
\text { pegawai } \\
c=12 \text { bulan }\end{array}$ & \\
\hline \multicolumn{3}{|c|}{ Total } & $\begin{array}{c}\text { Rp } \\
58.800 .000 \\
\end{array}$ \\
\hline \multicolumn{4}{|c|}{ Tabel 6 Meningkatkan Image Dari } \\
\hline No & $\begin{array}{c}\text { Meningkatkan } \\
\text { Image Dari }\end{array}$ & \begin{tabular}{l|l} 
Perhitungan \\
\end{tabular} & Total \\
\hline 1 & $\begin{array}{l}\text { Meningkatkan } \\
\text { image pegawai } \\
\text { karena tahu } \\
\text { menggunakan } \\
\text { aplikasi baru }\end{array}$ & $\begin{array}{l}\text { Rp } 50.000 \times \\
50 \% \times 14 \times 12 \\
a=\text { nilai } \\
\text { peningkatan } \\
\text { image } \\
\mathrm{b}=\text { presentase } \\
\text { peningkatan } \\
\text { image } \\
\mathrm{c}=\text { jumlah } \\
\text { pegawai } \\
\mathrm{d}=12 \text { bulan }\end{array}$ & $\begin{array}{l}\mathrm{Rp} \\
4.200 .000\end{array}$ \\
\hline \multicolumn{3}{|c|}{ Total } & $\begin{array}{c}\mathrm{Rp} \\
4.200 .000\end{array}$ \\
\hline
\end{tabular}

\subsection{Pendekatan Berbasis Value}

Untuk menghasilkan value yang optimal, maka dinilai perlu dilakukan kajian terhadap hal-hal yang bersifat intangible terhadap ranah Business, Technology, dan Organisation.

a. Ranah Business terbagi atas 2 bagian yaitu:

1. Dukungan terhadap sasaran strategi bisnis yaitu mengukur tujuan pembangunan proyek apakah dapat menunjang percepatan pencapaian tujuan strategis dari Kantor Sinode GMIM.

memiliki tupoksi kerja bagi setiap pegawainya. Setelah Kantor Sinode GMIM menggunakan aplikasi Pendataan Ekonomi Jemaat setiap pegawai tetap melakukan kerjanya masing-masing sesuai dengan tupoksi yang ada. Yang berubah hanyalah proses kerja itu sendiri yang telah dipengaruhi oleh sistem yang ada. Beberapa jenis kerja yang dulunya dilakukan secara manual, sekarang dilakukan dengan perangkat komputer sehingga para pegawai lebih cepat menganalisis pekerjaan dan tentu saja ada kepuasan tersendiri dari mereka. Peningkatan produktifitas pegawai dan meningkatkan image dari pegawai dapat dilihat pada tabel 5 dan 6 dibawah ini :

Tabel 5 Produktifitas Pegawai

\begin{tabular}{|c|l|l|l|}
\hline N & $\begin{array}{l}\text { Meningkatkan } \\
\text { Produktivitas } \\
\text { dari }\end{array}$ & Perhitungan & Total \\
\hline 1 & $\begin{array}{l}\text { Mempermudah } \\
\text { pegawai } \\
\text { menganalisis } \\
\text { pekerjaan }\end{array}$ & $\begin{array}{l}\text { Rp 100.000 x } \\
14 \text { x } 12 \\
\text { a= biaya } \\
\text { analisis } \\
\text { b= jumlah } \\
\text { pegawai } \\
\text { c=12 bulan }\end{array}$ & $\begin{array}{l}\text { Rp } \\
16.800 .000\end{array}$ \\
\hline 2 & $\begin{array}{l}\text { Meningkatkan } \\
\text { kepuasan pegawai } \\
\text { dalam kerjanya }\end{array}$ & $\begin{array}{l}14 \text { x 12 } \\
\text { a= taksiran } \\
\text { nilai kepuasan }\end{array}$ & $\begin{array}{l}\text { Rp } \\
42.000 .000\end{array}$ \\
\hline
\end{tabular}

2. Kepentingan proyek berhubungan dengan semakin besar resiko yang akan ditanggung perusahaan jika proyek tersebut tidak dilaksanakan secepatnya.

b. Ranah Organization terbagi atas 2 bagian yaitu:

1. Dukungan informasi terhadap manajemen berkaitan dengan seberapa penting informasi yang dihasilkan oleh sistem untuk membantu pengambilan keputusan dalam manajemen.

2. Kesiapan Sumber Daya Manusia TI pengembang proyek yaitu mengukur kualitas pihak yang berhubungan dalam pengembang proyek apakah sudah mampu mengembangkan proyek tersebut sesuai dengan spesifikasinya.

c. Ranah Technology terbagi atas 2 bagian yaitu:

1. Kesesuaian dengan cetak biru TI perusahaan yaitu mengukur kesesuaian proyek apakah merupakan salah satu bagian dalam rencana pengembangan TI perusahaan.

2. Kejelasan kebutuhan dan spesifikasi teknis yaitu mengukur apakah proyek yang akan dibangun merupakan pemecahan masalah bagi Kantor Sinode GMIM dilengkapi 
dengan kejelasan spesifikasi/ requirement yang diperlukan.

d. Scoring

Selanjutnya skor yang didapat ditinjau berdasarkan 5 kelas ukuran yaitu Buruk, Kurang, Cukup, Baik dan Sangat Baik. Pembobotan dan Scoring dapat dilihat pada table 7 dan Tabel 8 dibawah ini.

Tabel 7 Pembobotan

\begin{tabular}{|c|c|c|c|}
\hline \multirow[b]{2}{*}{ Ranah } & \multirow[b]{2}{*}{ Bobot } & \multicolumn{2}{|c|}{ Proyek TI } \\
\hline & & Skor & $\begin{array}{c}\mathrm{x} \\
\text { Bobot } \\
\end{array}$ \\
\hline \multicolumn{4}{|l|}{ I. $\quad$ BUSINESS } \\
\hline $\begin{array}{l}\text { 1. Dukungan terhadap } \\
\text { sasaran strategis } \\
\text { bisnis }\end{array}$ & 10 & 8 & 80 \\
\hline 2. Kepentingan Proyek & 10 & 6 & 60 \\
\hline \multicolumn{4}{|l|}{ II. $\quad$ ORGANIZATION } \\
\hline $\begin{array}{ll}\text { 1. } & \text { Dukungan } \\
& \text { informasi terhadap } \\
& \text { manajemen }\end{array}$ & 10 & 10 & 100 \\
\hline $\begin{array}{ll}\text { 2. } & \text { Kesiapan SDM TI } \\
\text { pengembang } \\
\text { proyek }\end{array}$ & 10 & 8 & 80 \\
\hline \multicolumn{4}{|l|}{$\begin{array}{ll}\text { III. } & \text { TECHNOLOGY } \\
\end{array}$} \\
\hline $\begin{array}{ll}1 . & \text { Kesesuaian dengan } \\
& \text { cetak biru TI } \\
& \text { perusahaan }\end{array}$ & 10 & 10 & 100 \\
\hline $\begin{array}{ll}\text { 2. } & \text { Kejelasan } \\
& \text { kebutuhandan } \\
& \text { spesifikasi teknis }\end{array}$ & 10 & 10 & 100 \\
\hline \multicolumn{3}{|c|}{ Total (skor x bobot) } & 520 \\
\hline
\end{tabular}

Tabel 8 Scoring

\begin{tabular}{|l|l|}
\hline Score & Hasil \\
\hline $0-120$ & Buruk \\
\hline $121-240$ & Kurang \\
\hline $241-360$ & Cukup \\
\hline $361-480$ & Baik \\
\hline $481=600$ & Sangat Baik \\
\hline & \\
\hline
\end{tabular}

Skor akhir dari investasi aplikasi pendataan ekonomi jemaat Kantor Sinode GMIM bernilai 520. Sesuai dengan tabel diatas, investasi ini berpredikat Sangat Baik, yang berarti penerapan aplikasi Pendataan Ekonomi Jemaat dinilai memberikan manfaat yang baik bagi Kantor Sinode GMIM.

\subsection{Pendekatan Berbasis Value}

Untuk mendukung proses perhitungan manfaat bisnis TI, penulis mengembangkan tools. Berikut adalah Tampilan Antar Muka tools Perhitungan Investasi TI berdasarkan metode IT Valuation Matrix.

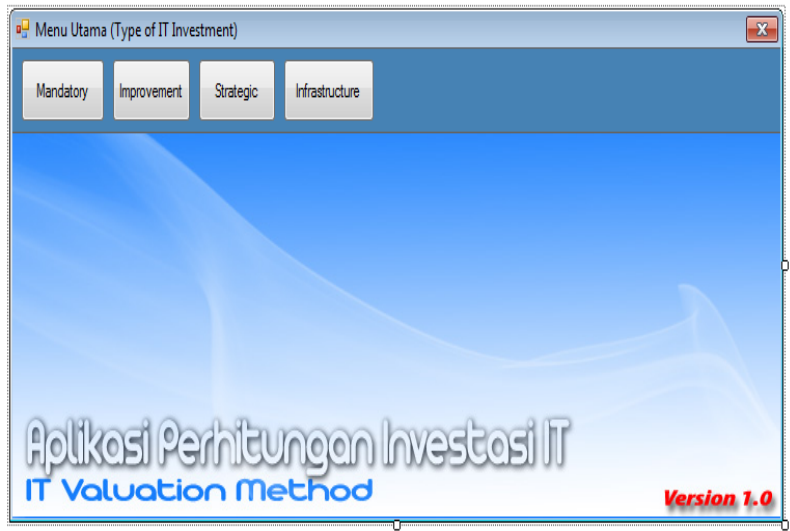

Gambar 4. Antarmuka Tools Perhitungan Investasi TI

\section{Kesimpulan}

Kesimpulan dari penelitian ini adalah:

1. Metode IT Valuation adalah cara untuk mengukur nilai investasi IT suatu organisasi atau perusahaan dengan menggunakan 2 (dua) pendekatan yakni biaya Finansial dan Non-Finansial.

2. Dikantor Sinode GMIM terdapat 4 kategori manfaat bisnis TI yaitu reducing cost, reducing risk, increasing productivity, increasing image.

3. Implementasi aplikasi Pendataan Ekonomi Jemaat diukur dari pendekatan NonFinansial bersifat sangat baik, berarti aplikasi ini memberikan manfaat bagi pihak Sinode GMIM terlebih dalam meningkatkan performa organisasi didalam pelayanan.

4. Formula yang digunakan dalam perhitungan manfaat bisnis dikantor Sinode GMIM diambil dari hasil kuisioner yang telah dibagikan kepada pegawai di kantor Sinode GMIM.

5. Implementasi aplikasi pendataan ekonomi Jemaat meningkatkan performa organisasi dalam berbagai aspek dilihat dari sisi efektif dan efisiensi, namun terdapat juga kelemahan yang ditemukan dalam segi perencanaan dan pemeliharaan TI yang nantinya akan berpengaruh dalam rangka pengembangan TI di Kantor Sinode GMIM.

\section{Referensi}

[1] Ranti, B. (2008). Identification of Information Systems/Information Technology Business Values with Hermeneutic Approach: Cases in Indonesia. Ph.D Thesis. Fakultas Ilmu Komputer, Universitas Indonesia.

[2] Ranti, B. (2006). Identifying of Businees Value of Information Technology using 
Hermeneutics. Workshop Prosiding, MoMM 2006 \& iiWASS 2006, p.695-699.

[3] Ranti, B. (2006). A Review of Information Technology Investment Evalution Methodologies: The Need for Approriate Evaluation Methods. Paper, Konferensi Nasional Teknologi Informasi dan Komunikasi Untuk Indonesia, ITB.

[4] Parker, M. (1988). Information Economics: Linking Business Performance to Information Technology. Prentice Hall, New Jersey.

[5] Parker, M. (1996). Strategic Transformation and Information Technology; Paradigm for Performing while Transforming. Prentice Hall, New Jersey.

[6] Bannister, F. Remenyi, D. (1999). Instinct and Value in IT Decision. Occasional Paper Series. Management Research Center, Wolverhampton Business School, University of Wolverhampton.

[7] Porter, M. E. (2008). On Competition. Harvard Business School Publishing Corp, Massachuttes-USA.
[8] Remenyi, D., Arthur, A., Sherwood-Smith, M. (2000), The Effective Measurement and Management of IT Costs and Benefits, $2^{\text {nd }}$ Edition, Elsevier.

[9] Stanley Karouw. (2011). Perencana Strategis Sistem Informasi/Teknologi Informasi berbasis Manfaat Bisnis TI dengan menggunakan Metodologi Be Vissta Planning Studi Kasus Dinas Pendapatan Daerah Sulawesi Utara., Paper Ilmiah, diterbitkan di Tekno, Edisi Desember 2011, ISSN:

[10] Dinas Pendapatan Daerah Provinsi Sulawesi Utara.(2006). Rencana Strategik Dinas Pendapatan Daerah Provinsi Sulawesi Utara Tahun 2006-2010.

[11] Karouw, Stanley (2009). Analisis Nilai Ekonomis Manfaat Bisnis SI/TI Guna Meningkatkan Pendapatan Asli Daerah Studi Kasus Dinas Pendapatan Daerah Provinsi Sulawesi Utara, Thesis. Fasilkom UI. 